\title{
Upper temperature tolerance of North Atlantic and North Pacific geographical isolates of Chondrus species (Rhodophyta)
}

\author{
K. Lüning ${ }^{1}$, M. D. Guiry ${ }^{2} \&$ M. Masuda ${ }^{3}$ \\ ${ }^{1}$ Biologische Anstalt Helgoland (Zentrale); Notkestr. 31, D-2000 Hamburg 52, Federal \\ Republic of Germany \\ ${ }^{2}$ Department of Botany, National University of Ireland, University College; Galway, \\ Ireland \\ ${ }^{3}$ Department of Botany, Faculty of Science, Hokkaido University; Sapporo, Japan 060
}

\begin{abstract}
The upper survival temperature for most isolates of Chondrus crispus from localities ranging from northern Norway and Iceland to Spain, and for an isolate from Nova Scotia, was $28^{\circ} \mathrm{C}$ after 2 weeks of exposure to temperatures of $20-31^{\circ} \mathrm{C}$ at intervals of $1{ }^{\circ} \mathrm{C}$. An upper survival limit of $29^{\circ} \mathrm{C}$ was exhibited by a few European isolates from the English Channel, the North Sea, and one Irish isolate from the upper intertidal. The warm-temperate Japanese species $C$. nipponicus and $C$. giganteus forma flabellatus survived $30^{\circ} \mathrm{C}$, whereas $29^{\circ} \mathrm{C}$ was the upper survival limit for the coldtemperature $C$. pinnulatus forma pinnulatus from northern Japan. A possible origin of $C$. crispus in the north Pacific is discussed.
\end{abstract}

\section{INTRODUCTION}

Do latitudinally widespread seaweed species exhibit constant temperature survival limits over their whole distributional range, or do they form a gradient of temperature ecotypes along a latitudinal gradient? Such temperature ecotypes have been found in the brown alga Ectocarpus siliculosus (Dillwyn) Lyngby, for which survival testing at intervals of $2-3^{\circ} \mathrm{C}$ (Bolton, 1983) showed that the uppermost survival temperature is $33^{\circ} \mathrm{C}$ for a strain from Port Aransas (Texas), $28^{\circ} \mathrm{C}$ for a strain from Wilmington (North Carolina), $25^{\circ} \mathrm{C}$ for a strain from Woods Hole (Massachusetts), and $23^{\circ} \mathrm{C}$ for a strain from the Canadian Arctic. In contrast, filamentous gametophytes of several geographical isolates of Laminaria saccharina (L.) Lamouroux, ranging from northern France to Norway, and of L. longicruris Bach. Pyl., from Nova Scotia to the Canadian Arctic, uniformly survived $23^{\circ} \mathrm{C}$, but not $24^{\circ} \mathrm{C}$ (Bolton \& Lüning, 1982). Whether temperature ecotypes similar to those of $E$. siliculosus exist in other geographically-widespread marine algae is unknown as, to date, very few species have been investigated as an array of geographical isolates.

The red alga Chondrus crispus Stackhouse, with a wide distribution in the North Atlantic and a possible origin in the North Pacific Ocean (van den Hoek, 1982), seemed to be a suitable species for continuing the search for possible temperature strains. To cope with the rather large number of geographical isolates of this species maintained by the second author, a system providing suitable incubation conditions for long-term treatment 
at different temperatures, with automatic and semi-continuous supply of enriched seawater, was devised and will be described in the present paper.

Isolates of C. nipponicus Yendo, referred to as Chondrus crispus Stackhouse in Mikami (1965), C. giganteus Yendo forma flabellatus Mikami, and C. pinnulatus (Harvey) Okamura forma pinnulatus from the coast of Japan were also tested in this system. These three species were included in the genus Chondrus by Mikami (1965) and Kim (1976) on the basis that they lack enveloping tissue around the carposporophyte and the tetrasporangia develop largely in the medulla. At present, it seems that of the extant Gigartinaceae, the above three species, $C$. ocellatus Holmes and $C$. yendoi Yamada et Mikami are most closely related to $C$. crispus.

\section{MATERIALS AND METHODS}

\section{Isolation and maintenance of strains}

Unialgal cultures of Chondrus crispus were isolated by M. Guiry from spores and vegetative tissue of plants collected at the localities listed in Table 1 . The Japanese species Chondrus nipponicus, C. giganteus forma flabellatus and C. pinnulatus forma pinnulatus were isolated from tetraspores by $M$. Masuda and sent as sporelings to $M$. Guiry's laboratory. Plants were grown to reproductive maturity at $15^{\circ} \mathrm{C}, 16 \mathrm{~h}$ of light at a photon fluence rate of $20-30 \mu \mathrm{mol} \mathrm{m}^{-2} \mathrm{~s}^{-1}$. These plants are being used in a study of the structure, reproduction and life history of Chondrus species from the Pacific (Brodie et al.; unpublished). For long-term culture maintenance, plants of Chondrus were grown at $15^{\circ} \mathrm{C}$ in Von Stosch's Enriched Seawater (VSES) at full strength (see Guiry \& Cunningham, 1984) and changed at intervals of 2-4 weeks; fluorescent light was used for $16 \mathrm{~h}$ light per day at a photon fluence rate of $30 \mu \mathrm{mol} \mathrm{m} \mathrm{m}^{-2} \mathrm{~s}^{-1}$ at $15^{\circ} \mathrm{C}$.

\section{Propagation of cultures and experimental material}

Unialgal cultures were sent in insulated cooling containers to the first author's laboratory in Hamburg and propagated for several months in crystallizing dishes $(90 \mathrm{~mm}$ in diameter), in similar conditions to those outlined above. Portions of thalli $10-20 \mathrm{~mm}$ long with at least one dichotomy were used in the temperature experiments.

\section{Incubation and automatic seawater replacement system}

Temperature experiments were carried out by placing plants in a series of 12 temperature-controlled water baths for two weeks. These were illuminated from above by fluorescent tubes (Fig. 1F; $16 \mathrm{~h}$ light per day at $30 \mu \mathrm{mol} \mathrm{m} \mathrm{m}^{-2} \mathrm{~s}^{-1}$ ). Each water bath contained 10 Plexiglas cylindrical jars (Fig. 1A, 1B) $(19.5 \mathrm{~cm}$ high, $3.5 \mathrm{~cm}$ in diameter, $140 \mathrm{ml}$ of culture medium) filled with VSES at half strength. The water baths, Haake D8-V water bath-cryostat units (Haake, Karlsruhe, FR Germany), with a volume of 15 l, dimensions $54 \times 36 \times 38 \mathrm{~cm}$, were selected as the smallest available unit equipped with a cooling system.

Water bath temperatures were measured daily, and deviations were found to be within the range $\pm 0.1^{\circ} \mathrm{C}$; twelve water baths were used at $1^{\circ} \mathrm{C}$ intervals from $20-31^{\circ} \mathrm{C}$ 

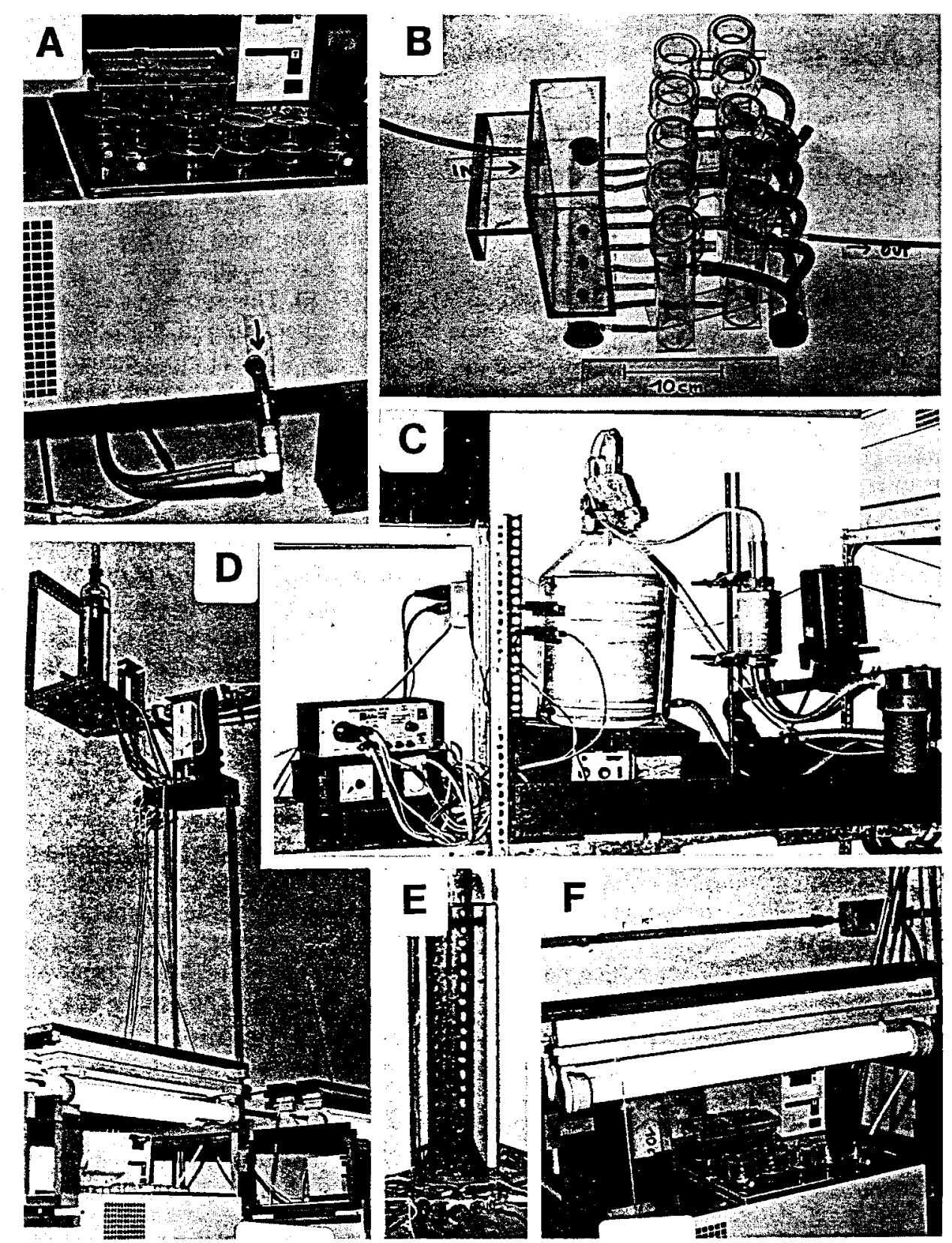

Fig. 1. Incubation and automatic seawater replacement system. (A) temperature-controlled water bath with incubation unit; (B) incubation unit consisting of 10 Plexiglas cylindrical jars and a rectangular inflow reservoir; (C) filter unit and 20-1 glass bottle for automatic preparation of enriched seawater; (D) 2.8-1 glass cylinder as a medium distributor (top), and electric pinch valve which controls seawater flow to water bath (bottom); (E) medium distributor (lower portion) in detail; (F) illumination unit on top of water bath 
inclusively. The culture medium in each of the 120 Plexiglas cylindrical jars was changed once a day; this procedure being automated as follows. Raw seawater from the house seawater system was first filtered through a polypropylene filter candle (type SEN 63254 PP1, $1 \mu \mathrm{m}$ pore size; Seitz Enzinger No 11, Bad Kreuznach, FRG) and then through a membrane filter candle (pore size $0.2 \mu \mathrm{m}$; type Sartobran capsule, or type Sartobran 11 combined with Sartopure GF; Sartorius, Göttingen, FRG). The filtered seawater entered a 20-1 glass bottle (Fig. 1C), which served as a reservoir, and received additional nutrients via a peristaltic pump from another glass bottle filled with autoclaved Von Stosch's stock enrichment medium. All connections consisted of autoclaved silicone tubing. The enriched seawater entered a 2.8-1 glass cylinder (Fig. 1D, E). This served as a medium distributor and evenly dispensed the medium from 12 outlets around the bottom via silicon dispensing tubes to $0.5-1$ Plexiglas reservoirs $(14 \times 7 \times 20 \mathrm{~cm}$ high) contained in each of the 12 water baths. The silicon dispensing tubes were passed through an electric pinch valve (Fig. 1D; modified from an air damper motor; type SMB 21, Landis and Gyr, Frankfurt-Main, FRG) which allowed water flow once an hour for a few seconds. The Plexiglas cylindrical jars containing the experimental algae received new culture medium from the Plexiglas reservoirs through an opening near the bottom of the cylindrical jar, $1 / 24$ of the jar volume being replaced every hour. An equivalent volume of "old" medium was displaced $8 \mathrm{~cm}$ from the top of the jar. This procedure of dividing up the daily culture medium supply into 24 parts and allowing temperature equilibration to take place within the Plexiglas reservoir in each water baths resulted in a negligible change of temperature $\left( \pm 0.1^{\circ} \mathrm{C}\right)$ during each hourly replacement of culture medium.

The quantity of half-strength VSES distributed in the above manner was automatically replaced in the 20-1 glass bottle reservoir (Fig. 1C) by using a modification of a system described earlier (Markham et al., 1979). This consisted of two photoelectric cells (type NGW level control regulator LR IV; Normschliff Gerätebau, Wertheim-Main, FRG) attached to the glass tube connected to the side of the 20-1 glass bottle which monitored the water level. When $5 \mathrm{l}$ of medium had been consumed, the lower photoelectric cell triggered the opening of a ball valve with an electrical actuator (G. Fischer AG, Albershausen, FRG) causing an inflow of raw seawater through the filters into the 20-1 glass bottle. The upper photoelectric cell actuated the closing of the ball valve and also started the peristaltic pump which added nutrient enrichment to the filtered seawater; the resulting half-strength VSES was agitated by a magnetic stirrer to ensure adequate mixing.

\section{Post-treatment and evalution}

After two weeks treatment at the experimental temperatures the thalli were transferred into $250-\mathrm{ml}$ screw-top bottles containing full strength VSES medium, and were postcultivated at $15^{\circ} \mathrm{C}$ in dim fluorescent white light (at about $10 \mu \mathrm{mol} \mathrm{m} \mathrm{m}^{-2} \mathrm{~s}^{-1}$, for $16 \mathrm{~h}$ of light per day). After 4 weeks the thalli were investigated visually or under a dissecting microscope. Three categories could normally be observed: (1) Up to a certain temperature $\left(\mathrm{X}^{\circ} \mathrm{C}\right)$ thalli had survived and exhibited normal colouration; (2) At $\mathrm{X}+1^{\circ} \mathrm{C}$, thalli appeared whitish or had fallen to pieces, but new thalli had regenerated from a few surviving cells. This "regeneration temperature " has been marked separately as " $(\mathrm{xx})$ " in Tables 1 and $2 ;$ (3) At $\mathrm{X}+2{ }^{\circ} \mathrm{C}$, and higher, thalli appeared as described, but no regeneration had taken place. If there was any doubt regarding these categories, the 
post-treatment was continued for another 4 weeks. All treatments were run in duplicate, and usually identical results were obtained after the first two runs. If not, further treatments were performed until the results of at least two treatments coincided (see Yarish et al. 1987, this volume, for further methodological aspects).

\section{RESULTS}

Most European strains of Chondrus crispus, ranging from northern Norway and Iceland to northern Spain, survived $28^{\circ} \mathrm{C}$; this was also true of the only strain investigated from the NW Atlantic (Table 1). The uniform survival temperature exhibited by these strains does not only relate to geographical origin, but also to other strain characteristics, i. e. different heights on the shore, the original phase from which a strain was isolated, and the sex of a strain (Table 1).

One degree of temperature more, i. e. $29^{\circ} \mathrm{C}$, was survived by a few European strains of Chondrus crispus, which did not come from the southern distributional range of the species as might be expected, but from the North Sea and English Channel area (strains from Germany, southern England, and northern France) as well as from one locality in Ireland.

As shown in Table 2, the Japanese strains of Chondrus nipponicus and C. giganteus forma flabellatus, both with a warm-temperature distribution in the western Pacific, consistently survived $30^{\circ} \mathrm{C}$, whereas the more cold-temperate $C$. pinnulatus forma pinnulatus only survived $29^{\circ} \mathrm{C}$; in this respect it is comparable with some strains of European C. crispus.

\section{DISCUSSION}

Two main findings will be discussed: (1) The upper temperature survival limit of Chondrus crispus appears to be rather uniform, at $28-29^{\circ} \mathrm{C}$, in spite of the welldocumented morphological plasticity (Darbishire, 1902; Thomas, 1938; Taylor \& Chen, 1973; Chen \& Taylor, 1980a, 1980b) and genetic differentiation at the isozyme level (Cheney \& Mathieson, 1979) of this species. If lack of evolution time within the North Atlantic is the reason for this uniform picture, then one might plausibly regard this, the only North Atlantic representative of the genus Chondrus, as being representative of the "recent" immigrants from the North Pacific Ocean, where there is more diversity within the genus. Nevertheless, if one wants to put weight on a difference of $1{ }^{\circ} \mathrm{C}$, a slight differentiation towards higher tolerance, i.e. survival at $29^{\circ} \mathrm{C}$, has been achieved by $C$. crispus in the "intermediate pocket" of the North Sea and English Channel, an area of somewhat greater seasonal seawater temperature fluctuations than the open Atlantic coast, where $C$. crispus isolates exhibit a survival temperature of $28^{\circ} \mathrm{C}$. Lüning (1984), however, also found that $28^{\circ} \mathrm{C}$ was the upper temperature limit for field material of $C$. crispus from Helgoland, but the next higher temperature he tested was $30^{\circ} \mathrm{C}$. The somewhat elevated tolerance of an Irish strain from upper intertidal pools, again only by $1{ }^{\circ} \mathrm{C}$ (Table 2; compare to other Irish strains), might point to small-scale directional selection as has been shown for salinity ecotypes in several seaweed species (see review by Russel, 1986). It might be interesting to perform further experiments with another large set of isolates but taken from one locality.

(2) Species of Chondrus from the North Pacific exhibit a slightly, but distinctly, 
Table 1. Chondrus crispus. Upper temperature tolerance of geographical isolates. Duration of treatment $=2$ weeks. Results evaluated after a post-treatment of 4 or 8 weeks at $15^{\circ} \mathrm{C} . \times \times \times \times$ whole thallus survived; $(x \times)$ regeneration from a few surviving cells; - - - whole thallus dead; phase treated: $m=$ male; $f=$ female gametophyte; phase of original plant isolated: $T=$ tetrasporophyte; $C$ $=$ cystocarpic plant $F=$ female plant

\begin{tabular}{|c|c|c|c|c|c|c|c|c|}
\hline \multirow[t]{2}{*}{ Strain } & \multirow[t]{2}{*}{ Habitat } & \multirow{2}{*}{$\begin{array}{l}\text { Culture } \\
\text { number }\end{array}$} & \multirow{2}{*}{$\begin{array}{l}\text { Ga- } \\
\text { meto- } \\
\text { phyte }\end{array}$} & \multicolumn{5}{|c|}{ Temperature over two weeks $\left({ }^{\circ} \mathrm{C}\right)$} \\
\hline & & & & 27 & 28 & 29 & 30 & 31 \\
\hline \multirow{6}{*}{$\begin{array}{l}\text { Iceland } \\
\text { (Eyrarbakki) }\end{array}$} & \multirow{4}{*}{$\begin{array}{l}\text { mid-inter- } \\
\text { tidal } \\
\text { unknown }\end{array}$} & \multirow[t]{2}{*}{$212(\mathrm{C})-2334$} & \multirow[t]{2}{*}{$\mathrm{m}$} & $x \times \times x$ & $x \times \times x$ & ---- & ---- & --- \\
\hline & & & & $\times \times \times \times$ & $\times \times \times \times$ & ---- & ---- & ---- \\
\hline & & \multirow[t]{2}{*}{$352(\mathrm{~T})-2373$} & \multirow[t]{2}{*}{$\mathrm{f}$} & $x \times \times \times$ & $x \times x \times$ & $-\div--$ & ---- & ---- \\
\hline & & & & $x \times \times \times$ & $\times \times \times \times$ & ---- & ---- & ---- \\
\hline & \multirow[t]{2}{*}{ unknown } & \multirow[t]{2}{*}{$353(\mathrm{~F})-2374$} & \multirow[t]{2}{*}{ f } & $x \times \times \times$ & $(x \times)$ & ---- & ---- & --- \\
\hline & & & & $\times \times \times \times$ & $(x \times)$ & ---- & ---- & ---- \\
\hline \multirow{4}{*}{$\begin{array}{l}\text { Norway } \\
\text { (Tromsö) }\end{array}$} & \multirow[t]{4}{*}{ unknown } & \multirow[t]{2}{*}{$351(\mathrm{~T})-2370$} & \multirow[t]{2}{*}{$\mathrm{m}$} & $\times \times \times \times$ & $(\times \times)$ & --- & ---- & ---- \\
\hline & & & & $x \times \times x$ & $(x \times)$ & ---- & ---- & ---- \\
\hline & & \multirow[t]{2}{*}{$351(\mathrm{~T})-2371$} & \multirow[t]{2}{*}{$\mathbf{f}$} & $x \times x \times$ & $x \times x \times$ & --- & ---- & ---- \\
\hline & & & & $x \times \times x$ & $\times \times \times \times$ & ---- & ---- & --- \\
\hline \multirow{4}{*}{$\begin{array}{l}\text { Scotland } \\
\text { (Fife Ness, Fife) }\end{array}$} & \multirow{4}{*}{$\begin{array}{l}\text { mid-inter- } \\
\text { tidal pools }\end{array}$} & \multirow[t]{2}{*}{$191(C)-2330$} & $\mathrm{~m}$ & $x \times \times x$ & $(x \times)$ & ---- & ---- & ---- \\
\hline & & & & $x \times x \times$ & $(x \times)$ & ---- & ---- & ---- \\
\hline & & $191(\mathrm{C})-2329$ & f & $x \times x \times$ & $(x \times)$ & ---- & ---- & ---- \\
\hline & & & & $x \times x \times$ & $(x \times)$ & ---- & ---- & ---- \\
\hline Ireland (Easky, & lower inter- & $312(T)-2365$ & $\mathrm{~m}$ & $x \times x \times$ & $x \times x \times$ & ---- & ---- & ---- \\
\hline Co. Sligo) & tidal rocks & & & $x \times x \times$ & $x \times x \times$ & ---- & ---- & ---- \\
\hline Ireland & upper inter- & $307(\mathrm{~T})-2363$ & $\mathrm{~m}$ & $x \times x \times$ & $x \times x \times$ & $(x \times)$ & ---- & --- \\
\hline (Spiddal, & tidal pools & & & $\times \times \times x$ & $\times \times \times x$ & $(x \times)$ & ---- & ---- \\
\hline Co. Galway) & & $307(T)-2364$ & f & $x \times x \times$ & $x \times x \times$ & $(x \times)$ & ---- & ---- \\
\hline & & & & $x \times \times \times$ & $x \times \times \times$ & $(x \times)$ & ---- & ---- \\
\hline Ireland & lower inter- & $306(C)-2360$ & $\mathrm{~m}$ & $x \times x \times$ & $(x \times)$ & ---- & ---- & --- \\
\hline (Muigh Inis, & tidal rocks & & & $x \times \times x$ & $(x \times)$ & ---- & ---- & ---- \\
\hline Co. Galway) & & $304(\mathrm{C})-2359$ & f & $x \times x \times$ & $x \times x \times$ & ---- & ---- & ---- \\
\hline & & & & $(x \times)$ & $(x \times)$ & ---- & ---- & ---- \\
\hline Ireland & mid-inter- & $301(\mathrm{~F})-2353$ & $\mathrm{~m}$ & $x \times x$ & $(x \times)$ & ---- & ---- & ---- \\
\hline (Fanore, & tidal pools & & & $(x \times)$ & $(x \times)$ & ---- & ---- & ---- \\
\hline Co. Clare) & & $301(F)-2354$ & f & $x \times x \times$ & $(x \times)$ & ---- & ---- & ---- \\
\hline & & & & $(x \times)$ & $(x \times)$ & ---- & ---- & ---- \\
\hline Wales (Broad- & lower inter- & $330(\mathrm{~T})-2366$ & $\mathbf{m}$ & $x \times x \times$ & $x \times x \times$ & ---- & ---- & ---- \\
\hline $\begin{array}{l}\text { haven, Pem- } \\
\text { brokeshire) }\end{array}$ & tidal rocks & & & $x \times \times \times$ & $x \times \times \times$ & ---- & --- & ---- \\
\hline England (Ply- & shallow & $208(C)-2333$ & f & $x \times x \times$ & $x \times x \times$ & ---- & ---- & --- \\
\hline mouth Sound) & subtidal & & & $x \times \times \times$ & $x \times x \times$ & ---- & ---- & --- \\
\hline England & floating & $295(C)-2351$ & $\mathrm{~m}$ & $x \times x \times$ & $x \times x \times$ & $(x \times)$ & ---- & --- \\
\hline (Hayling I.) & dock & & & $x \times x \times$ & $x \times x \times$ & $(\times x)$ & ---- & --- \\
\hline Germany & lower inter- & $286(C)-2344$ & $\mathrm{~m}$ & $\times \times \times \times$ & $(x \times)$ & $(x \times)$ & ---- & ---- \\
\hline (List, Sylt) & tidal & & & $x \times x \times$ & $x \times x \times$ & $(x \times)$ & ---- & ---- \\
\hline France (Grève & mid inter- & $392(\mathrm{~T})-2378$ & f & $x \times x \times$ & $x \times \times \times$ & $(\times x)$ & ---- & ---- \\
\hline St. Michel) & tidal rocks & & & $x \times x \times$ & $x \times x \times$ & $x \times x \times$ & ---- & --- \\
\hline Spain (Perbes, & lower inter- & $233(\mathrm{~T})-2337$ & f & $x \times x \times$ & $x \times x \times$ & ---- & ---- & ---- \\
\hline Galicia) & tidal & & & $x \times x \times$ & $x \times x \times$ & ---- & ---- & ---- \\
\hline Nova Scotia & upper inter- & $258(C)-2343$ & f & $x \times x \times$ & $(x x)$ & ---- & ---- & ---- \\
\hline $\begin{array}{l}\text { (Peggy's Cove, } \\
\text { Halifax) }\end{array}$ & tidal & & & $x \times x \times$ & $(x \times)$ & ---- & ---- & ---- \\
\hline
\end{tabular}


Table 2. Chondrus spp. from Japan. Upper temperature tolerance of geographical isolates (see Table 1 for further details)

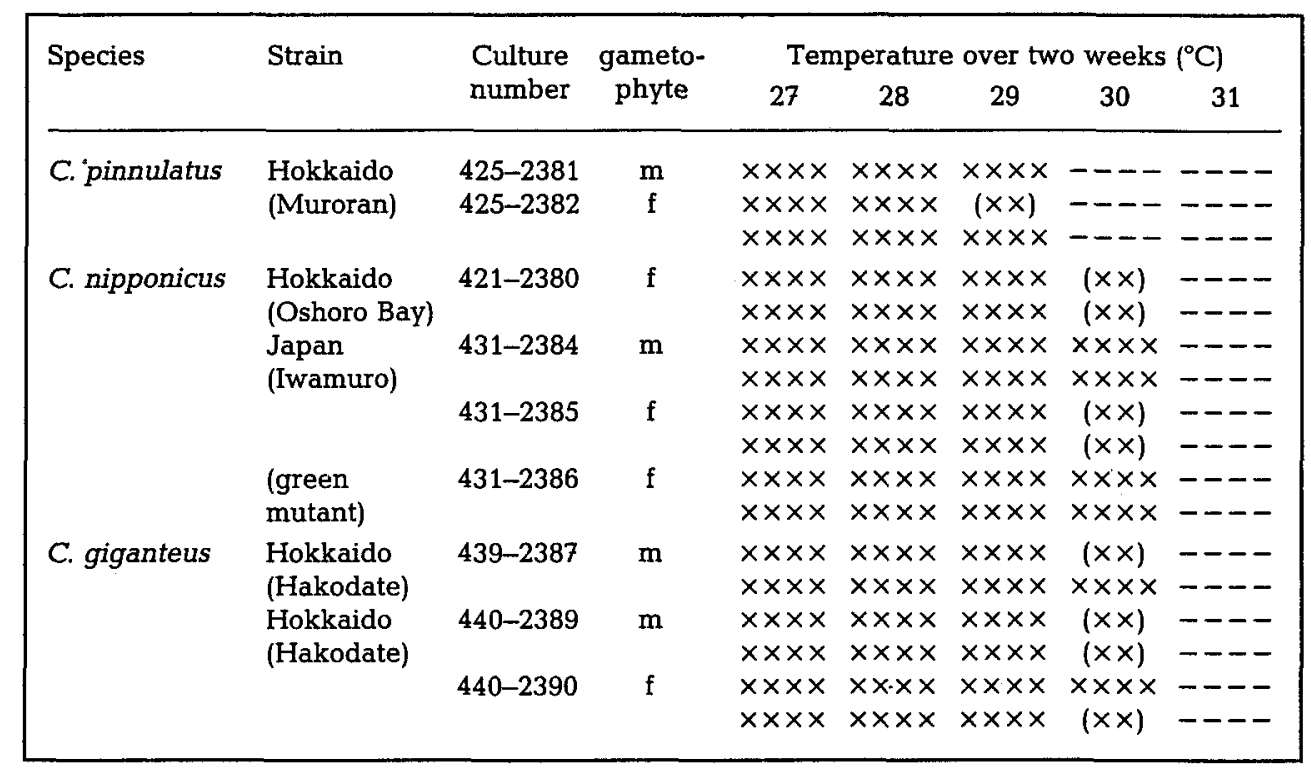

higher temperature tolerance of $1-2{ }^{\circ} \mathrm{C}$. Although these inter-oceanic differences should not be overemphasised, they bring to mind the findings of MacNeil (1965) and Strauch (1972) on the paleontological history of the gastropod genus Neptunea. In the course of the Tertiary this genus evolved an array of warm-to cold-temperate species in the North Pacific Ocean, but only one species ( $N$. lyrata) migrated into the North Atlantic Ocean, after the opening of the Bering land bridge (3.5 million years ago: cf. McKenna, 1983; Joosten \& van den Hoek, 1986). Since fossil evidence is largely lacking for macroalgae, it may be helpful for the phycologist to consider the evidence for mollusks and to discuss MacNeils's and Strauch's findings somewhat further.

Neptunea originated in the Eocene, some 50 million years ago, with one known fossil species in the warm Sea of Japan. During the Oligocene, three species were present in the NW Pacific and N. lyrata had reached the NE Pacific by the Miocene. The large bottom-crawling benthonic larva of this species, still known today, had "literally to crawl every inch of the way" (MacNeil, 1965, p. 5) through the newly-opened Bering Straits to the North Atlantic Ocean. The species "suddenly" appeared fossilized in northern Alaska, subsequently being found at Tjörnes (northern Iceland), and later on northwestern European shores. Intensive speciation near the Pliocene/Pleistocene boundary resulted in the formation of 23 recent species in the North Pacific (14 endemic to the NW region), while only 4 species evolved in the North Atlantic Ocean. Although the number of species of Chondrus is not so high, the distribution pattern may mirror a similar history. The main reason for this supposition is the existence of a North Pacific-Asiatic array of Chondrus spp. differing in latitudinal distribution, possibly in their temperature demands for growth and reproduction, and, slightly, but distinctly, in their upper survival temperature limit. 
Chondrus crispus, the type species of the genus Chondrus, is definitely known only from the North Atlantic. Reports of this species from the coast of Japan (see Mikami, 1965, and included references) are in error as the morphology and reproduction of Japanese plants are quite different from Atlantic plants. Furthermore, male and female isolates from Japan and various Atlantic localities do not cross in culture. Accordingly, C. crispus in Japan should be called C. nipponicus Yendo, the earliest available epithet (Guiry \& Masuda, unpubl.). This conclusion is further strengthened by the temperature tolerance data presented here. Kim (1976) in a study of the genera of the Gigartinaceae referred species of this family without enveloping tissue in the mature cystocarp to the genus Chondrus and species with enveloping tissue to the genus Gigartina (in which he included the genera Iridaea and Rhodoglossum). Two Japanese species included in Chondrus by Mikami (1965), C. elatus Holmes and C. verrucosus Mikami were transferred to Gigartina by $\mathrm{Kim}$ (1976) as he considered that they formed enveloping tissue. Chondrus canaliculatus (C. Agardh) Greville from South America was also transferred to Gigartina on this basis (as $G$. chilensis Kim). This proposal left $C$. crispus, C. giganteus, $C$. ocellatus, $C$. pinnulatus and $C$. yendoi in the genus Chondrus, although mention of a few other species of the genus was not made. Kim's concept of the genus was that the species lacked enveloping tissue in the cystocarp and that the tetrasporangia developed in the medulla rather than in the cortex and subcortex. Unfortunately, however, the true situation is probably a great deal more complicated than he appreciated.

There are many different types of tetrasporangial formation in the Gigartinaceae and at least two different types of gonimoblast tissue development. Additionally, the type species of Rhodoglossum, Iridaea and other genera of the family have not been adequately studied. It does seem likely that, given the range of variation in reproductive characters in the Gigartinaceae, intensive studies of the many described species will result in a complete reorganization, resulting perhaps in 5 or 6 genera. One thing is very clear, however: the number of species of Gigartinaceae in the North Pacific is very much larger than in the Atlantic.

Given that such a range of entities occurs in the north Pacific, it is not impossible that true Chondrus crispus or closely-related species do occur in this region, perhaps in Alaska or in the Aleutian Islands but have not been recognised. Chondrus platynus (C. Agardh) J. Agardh, originally described from Sakhalin Island, has been reported from Konyam Bay and Port Clarence (Kjellman, 1889) and the Pribilov Islands (Setchell, 1899) in the Bering Sea. Unfortunately, few details of the structure and reproduction of this species are known. The status of records of $C$. crispus from Unalaska and the Bering Sea (Setchell \& Gardner, 1903; Dawson, 1946) needs further investigation. Chondrus ocellatus forma parvus Mikami (1965) is reported from the Aleutian Islands South to Oregon (Abbott, 1969; Lindstrom, 1977) but Kim (1976; p. 69, footnote) refers the specimens on which these records are based to Gigartina cornucopiae (Postels et Ruprecht) Kim (= Iridaea cornucopiae Postels et Ruprecht). Abbott (1969; p. 52), however, clearly stated that the cystocarp in NE Pacific $C$. ocellatus had no enveloping tissue and that the tetrasporangia were formed in the medulla. It is clear that the generic placement of many Pacific Gigartinaceae remains confused.

It is possible that $C$. crispus became trapped in an almost isolated Arctic Ocean at the end of the Cretaceous when the Bering Straits closed, and invaded the North Atlantic Ocean after the Paleocene. The recently discovered early Tertiary marine intertebrate 
fauna at Ocean Point in northern Alaska, nowadays $40 \mathrm{~km}$ south of the Arctic Ocean coastline (Marincovich et al., 1985), comprised a peculiar mixture of relict "Cretaceous" taxa from the North Pacific and newly-evolved endemic taxa. Several taxa of the Ocean Point fauna, mainly mollusks and ostracods, are known after the Eocene as fossils, e. $g$. from the North Sea Basin, to where they could have migrated after the water exchange between the Arctic Ocean and Norwegian-Greenland Sea had been established near the end of the early Tertiary. If this was the way in which the North Atlantic Ocean obtained its Chondrus, then the relative constancy of the upper temperature limit during the whole of the Tertiary is even more impressive. The widening of the survival range towards lower temperatures, i. e. the first stage in the evolutionary change towards the development of Tertiary cold-water biota (cf. Scarlato, 1977), would then have occurred convergently in North Pacific and North Atlantic Chondrus spp.

Acknowledgements. We thank P. Kadel for her careful and diligent work; once the incubation system had been installed, she performed most of the experimental work. We are grateful to W. Guiry, I. Munda, D. Murphy and I. Tittley for assistance in collecting plants for culture and culture maintenance.

\section{LITERATURE CITED}

Abbott, I. A., 1969. Some new species, new combinations, and new records of red algae from the Pacific coast - Madroño, 20, 42-53.

Bolton, J. J., 1983. Ecoclinal variation in Ectocarpus siliculosus (Phaeophyceae) with respect to temperature growth optima and survival limits. - Mar. Biol. 73, 131-138.

Bolton, J. J. \& Lüning, K., 1982. Optimal growth and maximal survival temperatures of Atlantic Laminaria species (Phaeophyta) in culture. - Mar. Biol. 66, 89-94.

Chen, L. C.-M. \& Taylor, A. R. A, 1980a. Investigations of distinct strains of Chondrus crispus Stackh. I. Field and laboratory observations. - Botanica mar. 23, 435-440.

Chen, L. C.-M. \& Taylor, A. R. A., 1980b. Investigations of distinct strains of Chondrus crispus Stackh. II. Culture studies - Botanica mar. 23, 441-448.

Cheney, D. P. \& Mathieson, A. C., 1979. Population differentiation in the seaweed Chondrus crispus: preliminary results. - Isozyme Bull. $12,57$.

Darbishire, O. V., 1902. Chondrus - L. M. B. C. Mem. typ. Br. mar. Pl. Anim. 9, 1-42.

Dawson, E. Y., 1946. A guide to the literature and distributions of the marine algae of the Pacific Coast of North America - Mem. sth. Calif. Acad. Sci. 3 (1), 1-134.

Guiry, M. D. \& Cunningham, E. M. 1984. Photoperiodic and temperature responses in the reproduction of north-eastern Atlantic Gigartina acicularis (Rhodophyta: Gigartinales). - Phycologia 23, $357-367$.

Hoek, C. van den, 1982. Phytogeographic distribution groups of benthic marine algae in the North Atlantic Ocean. A review of experimental evidence from life history studies. - Helgoländer Meeresunters. 35, 153-214.

Joosten, A. M. T. \& Hoek, C., van den, 1986. World-wide relationships between red seaweed floras: a multivariate approach. - Botanica mar. 29, 195-214.

Kim, D. H., 1976. A study of the development of cystocarps and tetrasporangial sori in the Gigartinaceae (Rhodophyta, Gigartinales). - Nova Hedwigia 27, 1-146.

Kjellman, F. R., 1889. Om Beringhafvets algflora. - K. Svenska Vetensk. Akad. Handl. (Afd. 4) 23 (8), $1-58$.

Lindstrom, S. C., 1977. An annotated bibliography of the benthic marine algae of Alaska. - Tech. Rep. Alaska Dept. Fish Game 31, 1-172.

Lüning, K., 1984. Temperature resistance and biogeography of seaweeds: the marine algal flora of Helgoland, North Sea, as an example. - Helgoländer Meeresunters. 38, 305-317. 
McKenna, M. C., 1983. Cenozoic paleogeography of North Atlantic land bridges. In: Structure and development of the Greenland-Scotland ridge. Ed. by H. P. Bott, S. Saxov, M. Talwani \& J. Thiede. Plenum Press, New York, 351-399.

MacNeil, F. S., 1965. Evolution and distribution of the genus Mya, and Tertiary migrations of molluska. - Prof. Pap. geol. Surv. 483-G, 1-51.

Marincovich, L., Brouwers, E. M. \& Carter, L. D., 1985. Early Tertiary marine fossils from northern Alaska: implications for Arctic Ocean paleogeography and faunal evolution. - Geology 13, $770-773$.

Markham, J. W., Lüning, K. \& Sperling, K.-R., 1979. Automatic culture systems for growing Laminaria saccharina (Phaeophyceae) and testing the effects of pollutants. - Proc. int. Seaweed Symp. 9, 153-159.

Mikami, H., 1965. A systematic study of the Phyllophoraceae and Gigartinaceae from Japan and its vicinity. - Sci. Pap. Inst. algol. Res. Fac. Sci. Hokkaido (imp.) Univ. 5 (2), 181-285.

Russell, G., 1986. Variation and natural selection in marine macroalgae. - Oceanogr. mar. Biol. 24, 309-377.

Scarlato, O. A., 1977. Bivalve molluscs and temperature as an agent determining their geographical distribution. - Malacologia 16, 247-250.

Setchell, W. A., 1899. Algae of the Pribilof Islands. In: The fur seals and fur-seal islands of the North Pacific Ocean. Ed. by D. S. Jordan, Government Printing Office, Washington, D. C. 3, 589-596.

Setchell, W. A. \& Gardner, N. L., 1903. Algae of northwestern America. - Univ. Calif. Publs. Bot. 1, $165-418$.

Strauch, F., 1972. Phylogenese, Adaptation und Migration einiger nordischer mariner Molluskengenera (Neptunea, Panomya, Cyrtodaria und Mya). - Abh. senckenb. naturforsch. Ges. 531, $1-211$.

Taylor, A. R. A. \& Chen, L. C.-M., 1973. The biology of Chondrus crispus Stackhouse. Systematics, morphology and life history. - Proc. Nova Scotian Inst. Sci. 27 (Suppl.), 1-21.

Thomas, M., 1938. Der Formenkreis von Chondrus crispus und seine ökologische Bedingtheit. Hedwigia 77, 137-210.

Yarish, C., Kirkman, H. \& Lüning, K., 1987. Lethal exposure times and preconditioning to upper temperature limits of some temperate North Atlantic red algae. - Helgoländer Meeresunters. 41 , 323-327. 